\title{
MEMPERKENALKAN SEJARAH INDONESIA MELALUI PENYUTRADARAAN PROGRAM FEATURE "J URNAL MUSEUM" DENGAN PENDEKATAN NARATIF EPISODE: MUSEUM SANDI YOGYAKARTA
}

\author{
Yuzakki Gilang Fajar Bagaskara \\ Deddy Setyawan \\ Raden Roro Ari Prasetyowati
}

Jurusan Film \& Televisi, Fakultas Seni Media Rekam, Institut Seni Indonesia Yogyakarta Jl. Parangtritis km. 6.5 Yogyakarta Telp. (0274) 381047

\begin{abstract}
ABSTRAK
Program feature "Jurnal Museum" adalah sebuah karya program televisi yang membahas tentang sejarah baik perjuangan para pahlawan, kejadian di masa lalu, ilmu pengetahuan, kesenian, dan kebudayaan melalui museum-museum yang tersebar di seluruh daerah Indonesia. Pengalaman pribadi di masa anak - anak menjadi inspirasi perwujudan karya ini, selain itu alasan lainnya adalah ingin memperkenalkan kembali sejarah di Indonesia melalui museum - museum yang tersebar di seluruh Indonesia kepada anak-anak generasi sekarang.

Pada episode ini akan membahas tentang Museum Sandi yang berada di Daerah Istimewa Yogyakarta. Adapun alasan dipilihnya Museum Sandi yaitu karena terletak di pusat kota akan tetapi masih banyak yang belum mengetahuinya, selain itu sejarah tentang persandian di Indonesia juga masih belum banyak dikenal oleh masyarakat.a

Program "Jurnal Museum" memiliki tiga segment yang saling berhubungan membentuk alur perjalanan tokoh anak dan ayah. Pengemasan program feature "Jurnal Museum" ini menggunakan pendekatan naratif yang digambarkan melalui perjalanan tokoh anak dan ayah mengunjungi museum-museum di Indonesia. Pemilihan museum dalam setiap episodenya akan ditentukan oleh tokoh anak melalui pertanyaannya tentang hal-hal yang ada disekitarnya seperti sekolah, maupun kegiatan lainnya. Penjelasan tentang sejarah dan koleksi museum akan dibantu dengan media animasi. Animasi dipilih supaya lebih menarik dan informasi yang disampaikan mudah diterima oleh penontonnya yaitu anak-anak.
\end{abstract}

Kata Kunci: Program Feature, Naratif, Sejarah, Museum

\section{Pendahuluan}

Museum merupakan gedung yang digunakan sebagai tempat pameran tetap benda-benda yang patut mendapat perhatian umum, seperti peninggalan sejarah, seni, dan ilmu pengetahuan. Dikutip dalam koran Kompas edisi Rabu 21 Januari 2015 yang menyebutkan bahwa di Indonesia terdapat sekitar 400 museum. Jumlah tersebut merupakan jumlah yang cukup membanggakan maupun menggembirakan untuk masyarakat Indonesia karena telah terfasilitasi dalam pembelajaran untuk generasi - generasi berikutnya tentang peninggalan sejarah-sejarah yang berada di Indonesia, seni, maupun ilmu lainnya, akan tetapi saat ini minat masyarakat dalam kunjungan ke museum-museum mengalami penurunan. Tidak sedikit pihak museum yang mengeluh tentang kurangnya apresiasi 
masyarakat terhadap museum tersebut, hanya beberapa museum-museum yang dari awal memang sudah terkenal atau museum museum yang sudah menjadi landmark dari suatu kota yang masih menjadi tempat wajib dikunjungi saat berlibur. Dalam koran Kompas edisi Minggu, 23 November 2014, Direktur Pelestarian dan Cagar Budaya dan Museum, Harry Widianto menjelaskan bahwa ketidakrataan minat dan kunjungan masyarakat terjadi karena beberapa faktor yang masih menjadi hal yang perlu dievaluasi dan dicari solusinya. Hal tersebut merupakan salah satu hal yang melatarbelakangi penciptaan program Jurnal Museum ini.

Jurnal Museum direncanakan menjadi program televisi dengan format feature yang akan memberikan informasi mengenai museum-museum yang berada di Indonesia. Dalam setiap episodenya akan mengulas tentang sejarah dan koleksi-koleksi dari sebuah museum yang terdapat di suatu daerah. Program televisi Jurnal Museum memiliki target penonton anak - anak dengan umur 8-12 tahun. Penggunaan nama "Jurnal Museum" sebagai nama program acara dapat diartikan sebagai catatan harian tentang museum.

Penciptaan program televisi "Jurnal Museum” ini akan menggunakan pendekatan naratif atau sering disebut pendekatan bercerita. Naratif adalah suatu rangkaian peristiwa yang berhubungan satu sama lain dan terikat oleh logika sebab - akibat (kausalitas) yang terjadi dalam suatu ruang dan waktu (Himawan, 2008:33). Naratif berasal dari kata narasi yang memiliki makna pengisahan suatu cerita atau kejadian. Naratif adalah rangkaian kalimat yang bersifat narasi atau bersifat menguraikan menjelaskan, dalam makna lain naratif dikatakan sebagai prosa yang subjeknya merupakan suatu rangkaian kejadian. Pendekatan ini tidak selalu mengacu kejadian yang kronologis, namun peristiwa yang dirangkai memiliki hubungan tema yang saling terikat. Dalam pendekatan naratif, sutradara dapat mengelola bangunan cerita sesuai dengan keinginan dan tujuannya. Pendekatan naratif ini menjadi salah satu pendekatan yang cukup baik. Hal itu didasari, bahwa narasi atau kisah mudah menggerakan untuk bertindak dan mengembangkan proses imajinatif subyek didik. Kisah berperan menjadi jembatan antara yang dipikirkan dan pengalaman praktis. Naratif dalam hal ini tidak memberikan informasi secara langsung (to the point) kepada penonton akan tetapi lebih mengembangkan daya tangkap dan daya pikir dari penonton tersebut untuk menerima informasi yang disampaikan.

Tercetusnya ide penciptaan karya feature berjudul "Jurnal Museum" berasal dari pengalaman pribadi saat masih duduk dibangku TK-SD. Pengalaman tersebut berupa kunjungan ke museum-museum di Yogyakarta dengan orang tua disetiap akhir pekan. Selain itu ide lain penciptaan program 
televisi "Jurnal Museum" berasal dari keinginan untuk menciptakan sebuah program yang memberikan wawasan dan informasi tentang sejarah Indonesia melalui museum - museum yang berada di Indonesia kepada masyarakat umum terutama dikalangan anak - anak. Hal lain yang melandasi pengambilan topik museum dalam program ini adalah jumlah museum yang terbilang cukup banyak di Indonesia, akan tetapi tidak sedikit pula museum-museum tersebut yang kurang terapresiasi dan terbilang sepi. Program ini akan berfokus pada museum-museum yang berada di Indonesia. Dalam setiap episodenya, program ini akan menyajikan informasi mengenai sejarah dan koleksi - koleksi dari museum tersebut

Program feature "Jurnal Museum" ini berdurasi 24 menit dengan pembagian tiga segment di dalamnya. Dikemas dengan penceritaan ayah dan anak yang berkunjung ke museum-museum di Indonesia untuk menjawab pertanyaan yang timbul dari karakter anak tentang keresahan dan ketidaktahuan tentang hal-hal disekitarnya seperti mata pelajaran, hari-hari nasional, dan lain sebagainya. Fred Wibowo menjelaskan dalam bukunya Dasar - Dasar Produksi Program Televisi bahwa di dalam program feature terdapat unsur dokumenter, opini, dan ekspresi, akan tetapi perlu dipahami sekali lagi bahwa program feature bukanlah program dokumenter, melainkan program dimana berbagai macam format, baik yang bersifat opini maupun ekspresi dapat disajikan. Merujuk pada pengertian di atas, dalam program "Jurnal Museum" akan menggabungkan beberapa format diantaranya adalah cerita, dokumenter, intruksional dan kuis. Ketiga unsur di atas tidak semuanya digunakan pada program ini. Unsur dokumenter untuk menyajikan fakta mengenai koleksi-koleksi maupun sejarahnya.

Adapun program televisi lain yang menginspirasi penciptaan karya ini adalah "Program Pendidikan Sekolah" di TPI yang menyajikan ulasan mengenai mata pelajaran yang dipelajari di sekolah. Program tersebut digunakan sebagai referensi karena pengemasannya yang menggunakan pendekatan bercerita, dimana dalam program Jurnal Museum juga akan dikemas dengan pendekatan naratif/pendekatan bercerita, kemudian program acara "Si Otan" di Trans 7 yang membahas tentang binatang binatang yang berasal dari Indonesia maupun negara lain yang menggunakan animasi sebagai alat bantu dalam menjelaskan binatang - binatang dalam setiap rubriknya. Program "Jurnal Museum" akan mengadaptasi beberapa aspek dari kedua program tersebut, akan tetapi ada beberapa hal yang membedakan program "Program Pendidikan Sekolah" dan "Si Otan” dengan program "Jurnal Museum" yaitu tentang 
topik yang dibahas serta beberapa aspek lainnya.

Program “Jurnal Museum” dalam tiap episodenya akan disesuaikan dengan pertayaan yang didapat oleh tokoh anak. Pertanyaan tersebut dapat bersumber dari materi pelajaran, kegiatan ekstrakurikuler yang diikutinya, dan beberapa peringatan hari - hari di Indonesia (Seperti: Hari pendidikan, hari pahlawan dan sebagainya).

\section{Objek Penciptaan}

\section{Museum Sandi}

Museum Sandi adalah sebuah museum persandian yang kini berada di Kota Yogyakarta tepatnya di jalan Faridan Muridan Noto Nomor 21 Kotabaru, Yogyakarta 55224. Museum Sandi menampilkan berbagai koleksi persandian bersejarah. Museum ini dibangun atas prakarsa bersama antara Kepala Lembaga Sandi Negara RI, Mayjen TNI Nachrowi Ramli dengan Gubernur Daerah Istimewa Yogyakarta, Sri Sultan Hamengku Buwono X pada tahun 2006 dan diresmikan pada tanggal 29 Juli 2008.

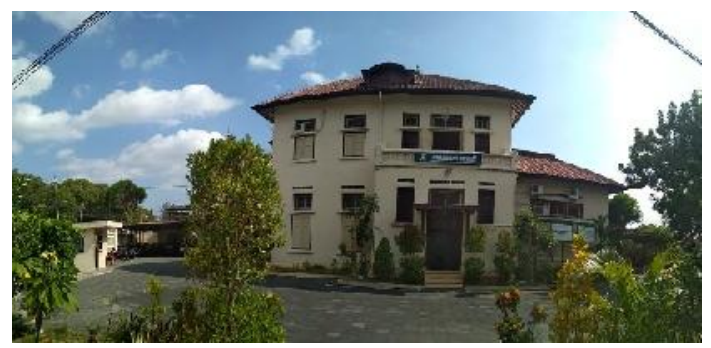

Gambar 1. Museum Sandi Yogyakarta (Dokumen Pribadi)
Berdasarkan Peraturan Pemerintah RI No. 19 Tahun 1995 tentang Pemeliharaan dan Pemanfaatan Benda Cagar Budaya di Museum, Lembaga Sandi Negara bekerja sama dengan Dinas Kebudayaan DIY berupaya melestarikan nilai-nilai sejarah persandian sebagai bagian integral perjuangan kemerdekaan Indonesia. Selain itu juga sebagai media penanaman nilai patriotisme untuk mewariskan nilai kejuangan kepada generasi penerus khususnya segenap insan persandian melalui sebuah museum yang dinamakan Museum Sandi. Koleksi dari Museum Sandi meliputi buku kode, tas kode, meja dan kursi yang digunakan pada tahun 1948, mesin sandi dan masih banyak lagi. Selain mendapatkan ilmu mengenai sejarah persandian pada masa agresi militer I dan II museum ini juga mengenalkan bagai mana cara membuat pesan sandi (kriptografi) secara sederhana.

Museum Sandi dipilih sebagai objek penciptaan pada episode ini karena letak museum yang sangat strategis di tengah perkotaan Yogyakarta akan tetapi banyak masyarakat tidak mengetahuinya. Menurut data yang diperoleh dari Museum Sandi tentang angka kunjungan masyarakat pada periode bulan Januari-Juli tahun 2018 menunjukkan angka 11.885 orang. Angka tersebut memang terbilang banyak, akan tetapi untuk jumlah kunjungan perharinya tidak stabil, terkadang mencapai 100 orang dalam sehari, hari berikutnya hanya 15 orang, 
selain itu dipilihnya Museum Sandi dikarenakan banyak masyarakat yang belum mengetahui bagaimana sandi juga berperan penting dalam kemerdekaan Indonesia.

\section{2. dr. Roebiono Kertopati}

dr. Roebiono Kertopati lahir di Tjiamis (Ciamis), 11 April 1914 merupakan Bapak Persandian Negara Indonesia. Sebelumnya ia adalah seorang dokter di Kementerian Pertahanan RI bagian B (intelijen). Pada tanggal 4 April 1946, dr. Roebiono Kertopati dengan pangkat Letkol. mendapat perintah dari Amir Syarifuddin, Menteri Pertahanan RI saat itu, untuk mendirikan sebuah badan yang mengelola persandian nasional.

dr. Roebiono Kertopati tidak mengenyam pendidikan persandian secara formal, namun hanya berupa kursus singkat pengenalan sandi dari kementerian luar negeri Belanda pada tahun 1949 melalui bacaan serta imajinasi, logika dan intuisi, diciptakanlah sistem-sistem sandi sendiri.

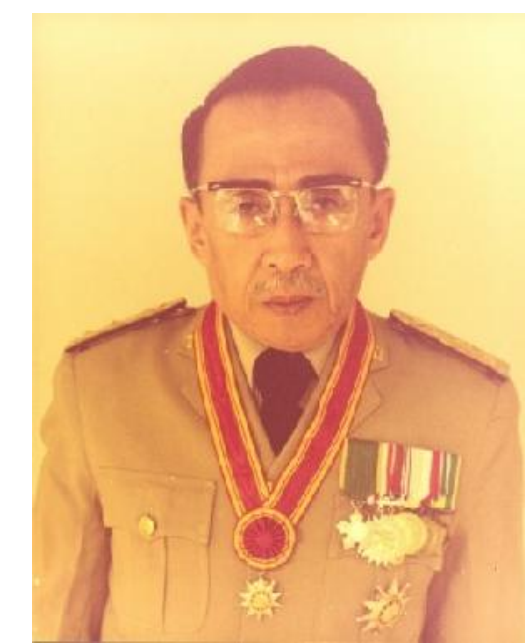

Gambar 2. Bapak dr.Roebiono Kertopati http://gardanasional.id/post/9130/BUMNTrack.com
Tanpa ilmu pengetahuan yang memadai mengenai teknis kriptografi dan hanya dibantu oleh tenaga-tenaga yang juga awam sandi, sistem-sistem sandi buatan sendiri tersebut terbukti efektif dan dapat diandalkan untuk mengamankan komunikasi berita di medan peperangan, di dalam perundingan-perundingan antara pemerintah RI dengan Belanda dan dengan PBB, pada komunikasi pemberitaan di perbatasan dan di dalam gerilya di daerah dan pedalaman.

\section{Konsep Karya}

Program acara "Jurnal Museum" akan membahas tentang museum-museum yang terdapat di Indonesia. Setiap episodenya hanya akan membahas 1 museum saja yang terdapat di suatu kota. Struktur program “Jurnal Museum" terdiri dari tiga segment, tiap segmentnya berdurasi delapan menit. Pendekatan naratif akan diterapkan pada pengadeganan tokoh ayah dan anak yang akan berkunjung ke museum untuk mencari jawaban atas keresahan/pertanyaan yang dimiliki oleh anak. Tokoh ayah dan anak dipilih karena kedekatan mereka didalam sebuah keluarga, selain itu jalannya program ini juga didukung oleh tokoh penjaga museum yang akan memaparkan informasi tentang koleksi - koleksi dari museum tersebut. Musim pertama "Jurnal Museum" ini memiliki 13 episode dan akan berfokus pada Daerah IstimewaYogyakarta. dimana yang akan memandu dalam musim ini adalah 
tokoh bernama Arbi dan keluarganya (Ayah dan Bunda).

Tokoh

a. Arbi (Anak)

Seorang anak berumur sebelas tahun yang duduk di kelas 5 SD. Memiliki proporsi tubuh yang ideal diseumurannya. Seorang anak yang memiliki rasa keingin tahuan yang tinggi tentang hal - hal seperti sejarah, teknologi, dan ilmu pengetahuan lainnya.

b. Ayah

Seorang pegawai disebuah industri kreatif, berumur tiga puluh tujuh tahun. Seorang ayah yang sayang keluarga dan dekat dengan anaknya. Memiliki kebiasaan mengajak anaknya mengunjungi tempat - tempat hiburan edukasi dan tempat - tempat peninggalan sejarah.

Penyampaian informasi pada program ini akan dipegang oleh tokoh penjaga museum, selain menjelaskan langsung, tokoh penjaga museum juga akan menjadi pengisi narasi di beberapa bagian seperti saat penjelasan koleksi - koleksi yang divisualisasikan kedalam bentuk animasi dua dimensi dan beberapa koleksi yang dijelaskan dengan bantuan motion graphic. Animasi dua dimensi akan digunakan untuk membantu menjelaskan tentang latar belakang dari beberapa koleksi. Digunakannya animasi karena tidak didapatkannya dokumentasi resmi dari koleksi - koleksi tersebut pada masanya. Penggunaan animasi dua dimensi pada program ini akan berfokus di segment 2 dan segment 3 dimana pada segment tersebut akan dibahas tentang sejarah persandian di Indonesia melalui ruang agresi militer 1, ruang replika rumah sandi, dan ruang agresi militer 2.

Konsep videografi pada program "Jurnal Museum" bervariasi. Dalam program acara ini lebih menggunakan gambar yang sesuai kebutuhan dengan realitas yang ada dan tidak melupakan aspek keindahannya. Hal ini bertujuan agar penonton dapat mendapatkan informasi yang disampaikan melalui visual dan pemaksimalan keindahan dalam visualnya dengan gambar - gambar dinamis dengan variasi pergerakan kamera yang disesuaikan agar tidak muncul rasa jenuh saat melihatnya. Penggunaan shot size pada kedua tokoh ayah dan anak lebih sering menggunakan shot - shot padat seperti medium shot hal ini dikarenakan untuk memberi kesan kedekatan pada kedua tokoh.

Untuk konsep penggarapan videografi untuk masing - masing segment sebagai berikut:

\section{Segment 1}

Konsep pengambilan gambar pada segment ini lebih banyak menggunakan medium shot untuk memperlihatkan kedekatan antara tokoh ayah dan anak yang sedang berinteraksi 
di ruang keluarga. Kemudian ada beberapa penggunaan point of view dari kedua tokoh. Selain itu full shot akan digunakan saat mereka sudah berada di Museum Sandi untuk memperlihatkan keseluruhan bangunan museum dan ruangannya.

\section{Segment 2}

Pada segment 2 dan 3 akan digunakan beberapa variasi shot seperti medium shot, medium close up, close up, dan full shot. Close up akan digunakan untuk melihat detail dari koleksi koleksi museum. Kemudian akan menggunakan komposisi rule of third yang digunakan memberikan ruang untuk grafis tentang informasi yang perlu ditampilkan.

\section{Segment 3}

Pada segment terakhir ini penggunaan pengambilan gambar akan hampir sama seperti pada segment 1 akan tetapi akan ditambahkan beberapa close up pada koleksi - koleksi museum dan bagian buku jurnal yang berisi kunjungan - kunjungan mereka ke museum

Penataan cahaya dalam program ini disesuaikan dengan lokasi pengambilan gambar. Menggunakan dua lokasi utama yaitu ruang rumah dan museum. Pencahayaan yang digunakan di rumah menggunakan color temperature yang relatif hangat, hal ini ditujukan untuk memberi kesan kehangatan hubungan tokoh ayah dan anak. Untuk pencahayaan di museum harus baik dan disesuaikan dengan kondisi di tempat. Available light digunakan dalam pengambilan gambar outdoor.

Konsep editing dibuat dengan mengutamakan kebutuhan konten dari masing - masing segment. Konsep tersebut akan diterapkan dengan pemilihan gambar gambar yang sesuai dengan informasi yang akan ditampilkan dan disampaikan. Tempo cutting yang digunakan akan lebih sedikit lambat karena akan memperlihatkan kedekatan dari kedua tokoh. Untuk transisi ke animasi dua dimensi akan menggunakan wipe transition.

Konsep animasi dua dimensi akan menggunakan desain vector dengan tipe flat design. Penggunaan animasi dengan flat design dipilih karena lebih simpel dan tetap menarik. Pada program ini animasi digunakan untuk membantu menjelaskan koleksi - koleksi museum serta sejarah persandian di Indonesia. Penggunaan animasi dipilih karena tidak didapatkan dokumentasi asli latar belakang dari koleksi - koleksi yang ada, akan digunakan juga motion graphic sebagai penunjang penyampaian informasi lainnya. 


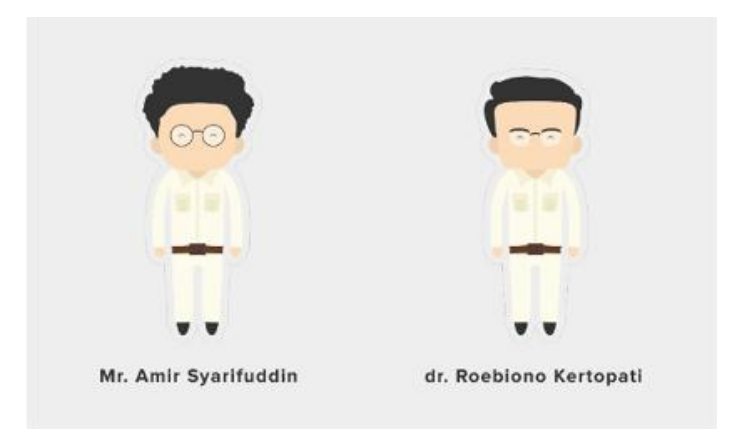

Gambar 3. Rancangan karakter animasi yang digunakan

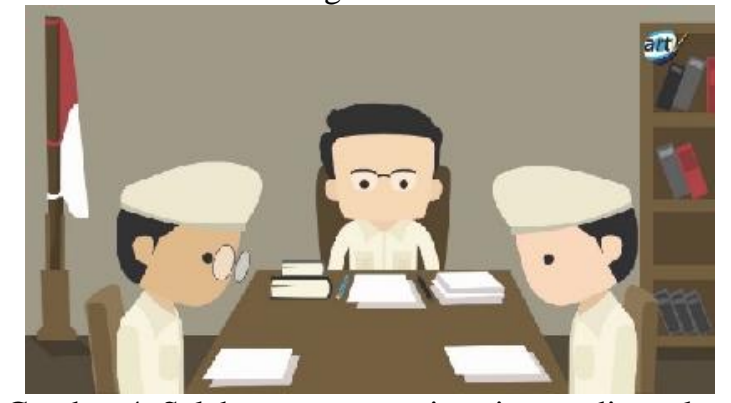

Gambar 4. Salah satu scene animasi yang digunakan

\section{Pembahasan}

Program feature "Jurnal Museum" akan berdurasi 24 menit dengan pembagian tiga segment. Ketiga segment akan menjadi satu kesinambungan alur cerita tentang kunjungan Ayah dan Arbi di Museum Sandi.

\section{Segment 1}

Segment ini menjelaskan bagian awal cerita dari perjalanan Ayah dan Arbi mengunjungi Museum Sandi. Pada segment 1 ini diawali dengan pertanyaan Arbi kepada Ayah mengenai sandi yang didapatkannya dari ekstrakurikuler pramuka. Hal tersebut membuat Ayah mengajak Arbi berkunjung ke Museum Sandi untuk mencari jawaban atas pertanyaannya.

Segment 1 dibuka dengan adegan Arbi menghampiri Ayahnya yang baru saja pulang kerja di ruang tamu. Arbi menyambut Ayahnya dengan pertanyaan tentang persandian yang didapatkan di ekstrakulikuler pramuka. Pertanyaan yang dilontarkan Arbi adalah seputar pengertian sandi dan apakah sandi pernah digunakan semasa perjuangan rakyat Indonesia dalam mencapai kemerdekaan.

Pada scene 1 ini unsur naratif sebabakibat dibangun. Scene pertama ini berfungsi sebagai penentu topik bahasan dan museum yang akan dikunjungi melalui pertanyaan dari Arbi kepada Ayahnya. Arbi menanyakan tentang pengertian sandi dan apakah sandi digunakan saat perjuangan kemerdekaan di Indonesia. Pertanyaan pertama merupakan pertanyaan mendasar yang jarang dijelaskan ketika ekstrakulikuler pramuka, biasanya materi langsung masuk ke sandi apa yang akan dipelajari tanpa menjelaskan pengertian dasar tentang sandi itu sendiri. Pertanyaan kedua merupakan perkembangan dari pertanyaan pertama, dimana pada penjelasan Ayah tentang sandi merujuk pada kemiliteran, sehingga muncul pertanyaan tentang kegunaan sandi di masa perjuangan Indonesia. Pertanyaan tersebut kemudian merujuk ke Museum Sandi dan sejarah persandian di Indonesia.

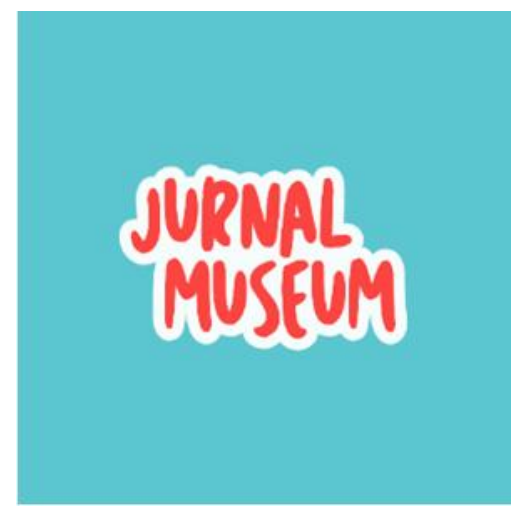

Gambar 5. Logo program yang digunakan (Dokumen Pribadi) 
Pada program "Jurnal Museum” ini Arbi berperan penting menentukan topik dan museum yang akan dibahas melalui pertanyaan tentang hal-hal disekitarnya. Scene pertama ini terletak sebelum bumper program sebagai pengantar tentang topik yang akan dibahas di episode ini.

Scene berikutnya merupakan bumper program "Jurnal Museum". Bumper program "Jurnal Museum" menggunakan flat design, yaitu desain dengan pendekatan minimalis, bersih tanpa adanya bevel, bayangan, tekstur, dan lebih berfokus pada tipografi, warnawarna cerah yang tidak mencolok, serta ilustrasi dua dimensi. Warna-warna yang digunakan pada bumper disesuaikan dengan grafis lainnya agar tetap selaras dari awal sampai akhir program. Pada bumper program ini diperlihatkan beberapa ikon yang menggambarkan kategori museum seperti untuk kesenian, sejarah, dan ilmu pengetahuan.

$$
\text { Scene setelah bumper }
$$

memperlihatkan kegiatan keluarga Arbi yang sedang bersiap-siap berangkat menuju Museum Sandi. setelah itu diperlihatkan juga footage seperti simpang empat 0 (Nol) Kilometer dan Tugu Jogja untuk menunjukkan lokasi yaitu di Daerah Istimewa Yogyakarta. Pada bagian ini juga diperlihatkan grafis tentang denah lokasi Museum Sandi.

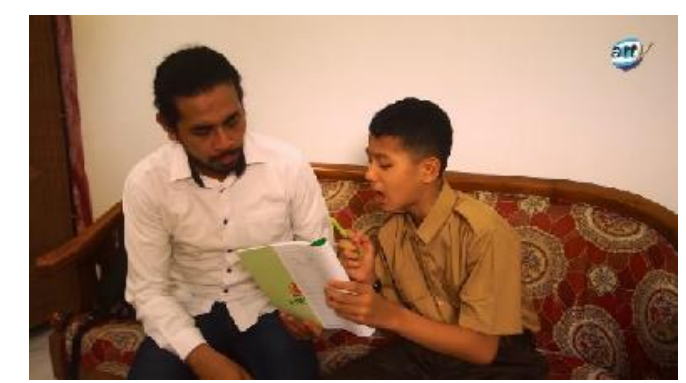

Gambar 6. Screenshot adegan Arbi bertanya kepada Ayah

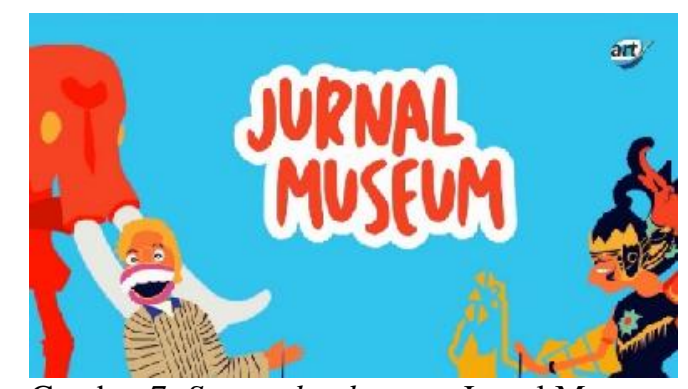

Gambar 7. Screenshot bumper Jurnal Museum

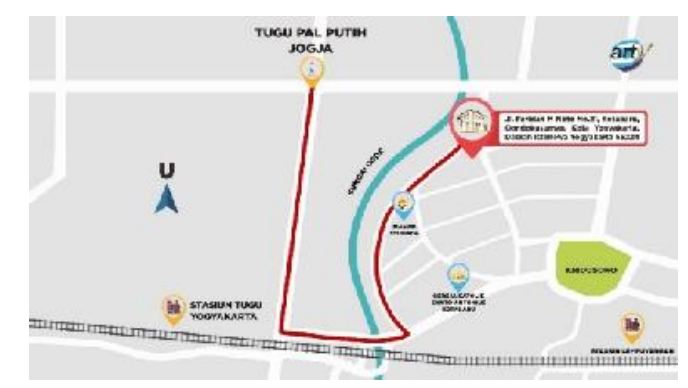

Gambar 8. Screenshot grafis lokasi Museum Sandi

Scene berikutnya sudah bertempat di Museum Sandi. Memperlihatkan Arbi dan Ayah. sampai di halaman Museum Sandi. Adegan berikutnya adalah Arbi dan Ayah mulai masuk ke Museum Sandi. Ruangan pertama yang diperlihatkan adalah lobby museum. Pada kunjungan ke setiap ruangan akan dimulai dengan footage-footage bendabenda dan interior dari ruangan tersebut untuk menunjukkan detail-detail yang ada.

$$
\text { Pada scene di lobby terjadi }
$$
percakapan antara Ayah dan petugas museum Ima yang membahas tentang informasi umum seperti harga tiket museum dan tata cara masuk ke Museum Sandi. Scene ini juga 


\section{Yuzakki Gilang Fajar Bagaskara, Deddy Setyawan, Raden Roro Ari Prasetyowati}

Memperkenalkan Sejarah Indonesia Melalui Penyutradaraan Program Feature "JURNAL MUSEUM"

memperlihatkan tokoh Arbi yang mempunyai rasa keingintahuan tinggi dengan memperlihatkan Arbi yang berkeliling sendiri melihat benda-benda yang ada disekitarnya. Setelah Ayah selesai menulis buku tamu, Ayah dan Arbi menghampiri petugas museum Muna yang akan menjadi edukator/tour guide dalam kunjungan kali ini.

Pada episode ini Petugas Muna bertugas sebagai penyampai informasi tentang sejarah persandian dan informasi tentang koleksi-koleksi yang ada di Museum Sandi. Pada scene di lobby ini Petugas Muna menjelaskan secara singkat informasi tentang Museum Sandi.

Scene berikutnya merupakan akhir dari segment 1, dan merupakan awal dari perjalanan Ayah dan Arbi ditemani petugas Muna menjelajahi ruangan di Museum Sandi. Ruangan pertama adalah ruang Agresi Militer I yang menjelaskan awal terbentuknya Dinas Kode. Ruangan ini memiliki koleksi berupa diorama pembentukan dinas kode, buku kode $\mathrm{C}$, tas kode, dan peta pesebaran kode. Informasi mengenai koleksi-koleksi tersebut akan disampaikan oleh petugas Muna dengan menjawab beberapa pertanyaan yang dilontarkan Arbi.

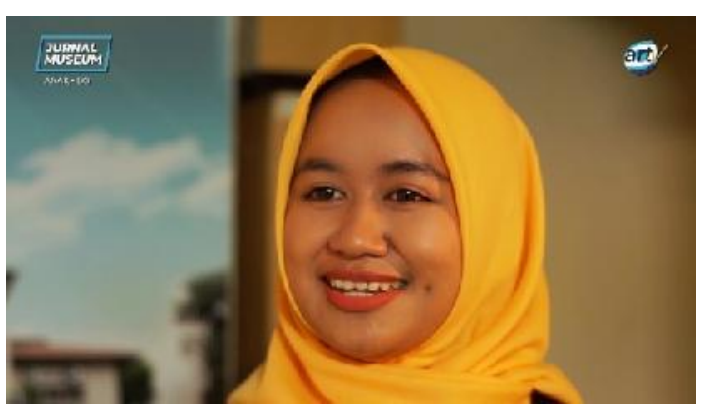

Gambar 9. Screenshot Petugas Museum Muna

Pada scene Ruang Agresi Militer I ini penjelasan informasi koleksi-koleksi dibantu dengan animasi dan grafis. Tidak adanya berkas penunjang koleksi-koleksi, maka dibuatlah animasi sebagai media bantu penjelas latar belakang dari koleksi yang ada. Dipilihnya animasi karena lebih menarik untuk penonton yang dituju yaitu anak-anak. Pada penjelasan animasi petugas Muna berubah fungsi menjadi narator. Penggunaan petugas Muna sebagai narator dimaksudkan untuk menjaga kontinitas dari pemapar informasi.
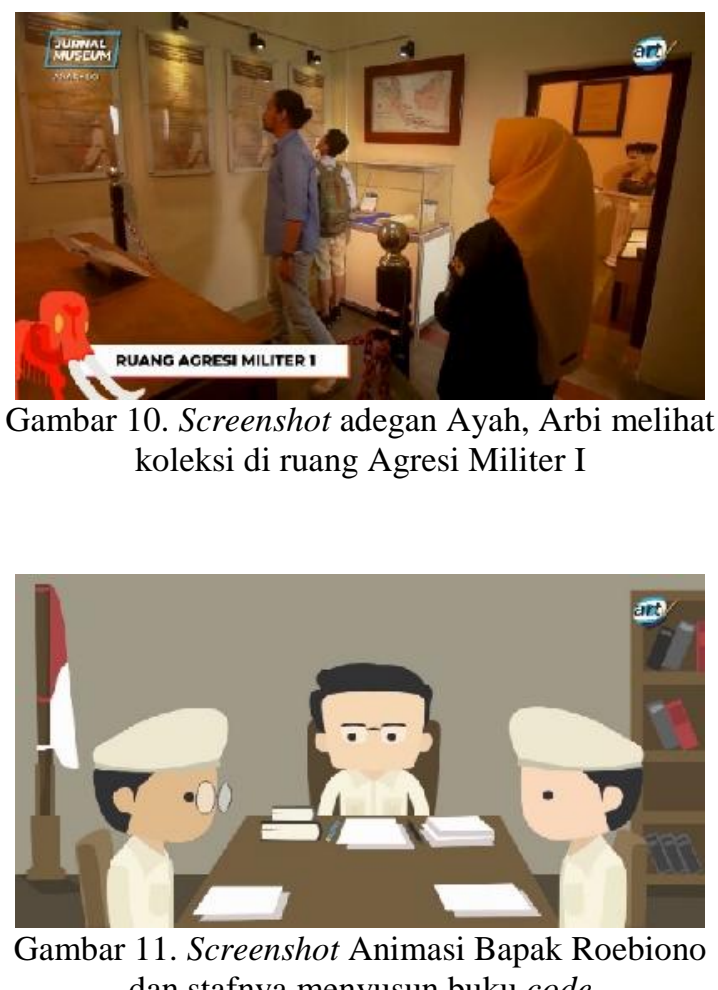
dan stafnya menyusun buku code 


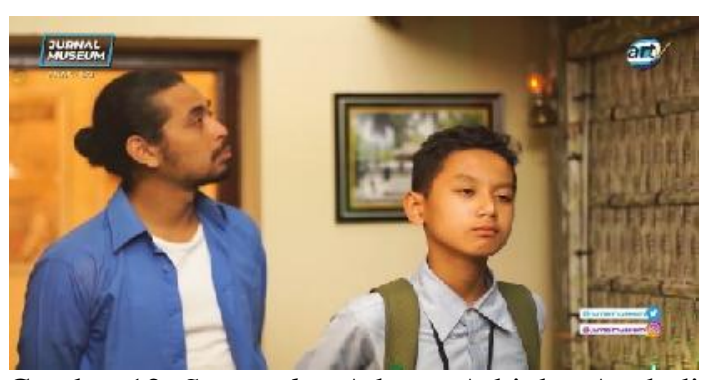

Gambar 12. Screenshot Adegan Arbi dan Ayah di Ruang Replika Rumah Sandi

\section{Segment 2}

Segment 2 merupakan kelanjutan perjalanan Ayah dan Arbi menjelajah Museum Sandi. Pada segment ini cerita tentang sejarah persandian memasuki babak puncak dan akhir perjuangan. Segment 2 hanya terdiri dari dua scene, yaitu ruang replika rumah sandi dan ruang agresi militer II. Setiap scene di segment ini juga memiliki beberapa sequence animasi dua dimensi sebagai media pembantu untuk menjelaskan sejarah dari koleksi-koleksi museum.

Scene pertama pada segment ini berlokasi di ruang replika rumah sandi atau biasa disebut maket dukuh. Ruangan ini menjelaskan tentang sebuah rumah di daerah Kulonprogo yang digunakan Bapak Roebiono dan stafnya sebagai markas darurat dinas kode semasa agresi militer Belanda di Yogyakarta. Scene ini juga akan diawali dengan footage-footage interior dari replika rumah sandi, shot berikutnya akan masuk adegan petugas Muna menjelaskan kepada Ayah dan Arbi tentang apa yang ada di ruangan tersebut.

Pada scene ini terdapat animasi untuk membantu menjelaskan latar belakang dari rumah sandi tersebut. Sequence animasi ini merupakan lanjutan dari sequence animasi yang terdapat di scene terakhir pada segment 1. Animasi pada scene ini menjelaskan tentang perjalanan Bapak Roebiono dan stafnya ke barat menuju pulau Sumatra yang dikarenakan Belanda melakukan agresi ke Yogyakarta. Perjalanan tersebut melewati daerah Kulonprogo, kemudian Bapak Roebiono dan stafnya singgah di salah satu rumah warga setempat untuk beristirahat. Bapak Roebiono merasa cocok dengan rumah warga setempat tersebut dan akhirnya digunakan sebagai markas darurat dinas kode.

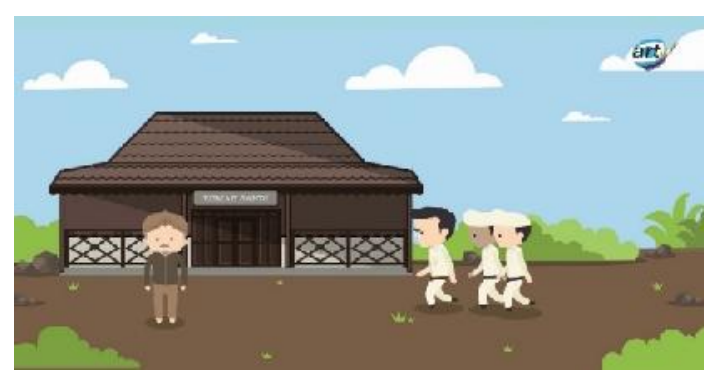

Gambar 13. Screenshot animasi Rumah Sandi

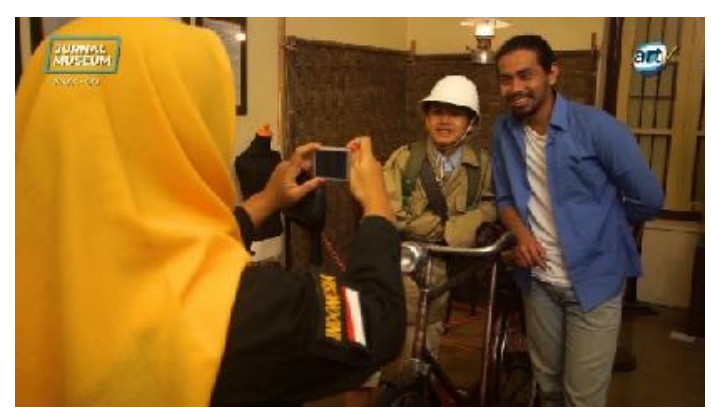

Gambar 14. Screenshot adegan petugas Muna memfoto Arbi dan Ayah

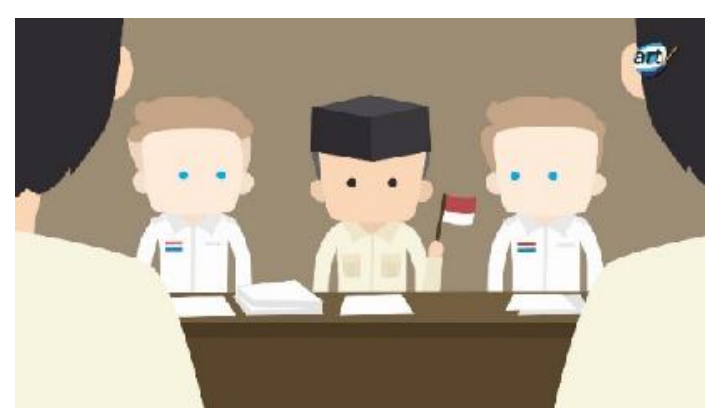

Gambar 15. Screenshot animasi pengakuan kemerdekaan Republik Indonesia 
Scene berikutnya memperlihatkan lanjutan perjalanan Ayah dan Arbi di ruangan agresi militer II. Ruangan ini menceritakan akhir dari perjuangan dinas kode hingga diakuinya kemerdekaan Republik Indonesia oleh Belanda pada konfrensi meja bundar di Den Haag. Ruangan ini memiliki koleksi seperti sepeda onthel yang dipakai kurir mengirim pesan, meja dan kursi kassa dari rumah sandi, replika radio yang digunakan pada akhir masa dinas kode, dan replika stasiun radio Pemerintah Darurat Republik Indonesia di Sumatra. Pada scene ini dilakukan eksplorasi pada koleksi yang ada di ruangan tersebut dengan menambahkan adegan Ayah dan Arbi berfoto dengan sepeda onthel dan seragam pejuang.

Pada scene ini juga terdapat animasi sebagai penjelas koleksi sepeda onthel dan radio komunikasi. Sequence animasi ini menjelaskan tentang radio milik Indonesia yang digunakan sebegai alat komunikasi dengan perwakilan Indonesia di luar negeri. Radio ini sempat direbut oleh tentara Belanda pada Serangan Umum 1 Maret. Hingga akhirnya Indonesia diakui kemerdekaannya pada konfrensi meja bundar di Den Haag tahun 1949.

Sequence animasi tersebut merupakan lanjutan sequence animasi sebelumnya dan merupakan sequence terakhir yang menjelaskan tentang sejarah persandian di Indonesia.

\section{Segment 3}

Segment terakhir ini menjelaskan tentang ruangan yang berada di lantai atas Museum Sandi serta penutup pada episode kali ini. Pada segment ketiga ini informasi yang disampaikan lebih ringan dari ketiga ruangan sebelumnya. Terdapat empat scene di museum dan satu scene di rumah sebagai penutup episode. Pada segment ketiga ini terdapat sebuah instruksional yang dijelaskan dengan animasi tentang sandi geser sebagai suvenir Museum Sandi.

Scene pertama segment 3 berlokasi di tangga menuju lantai kedua Museum Sandi. Scene ini juga berfungsi sebagai transisi dari lantai pertama dengan lantai kedua. Pada scene ini tidak ada informasi penting yang disampaikan hanya memperlihatkan detail interior museum. Ketiga tokoh diperlihatkan menaiki tangga sambil melihat-lihat foto yang terdapat disepanjang tangga.
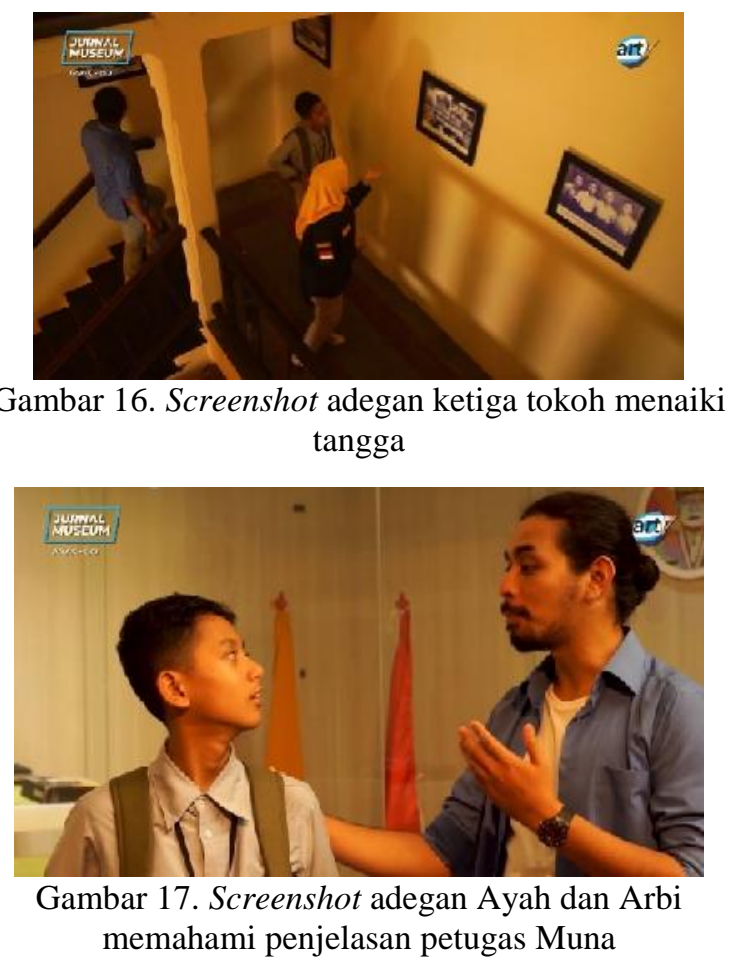
Perjalanan Arbi dan Ayah berlanjut ke ruangan berikutnya yaitu ruang tokoh. Ruangan ini berisi koleksi pribadi dari Bapak Roebiono dan kepala sandi negara setelahnya. Pada scene ini pengadeganan digunakan hanya sebagai pengantar masuk ruangan dan keluar ruangan, selebihnya informasi dijelaskan melalui narasi dari Petugas Muna dan footage-footage.

Scene berikutnya merupakan penutup dari jelajah museum yang dilakukan Arbi dan Ayah. Ruangan terakhir yang dikunjungi adalah ruang edukasi atau ruang instruksional. Scene ini berisi kuis dari petugas Muna untuk Ayah dan Arbi tentang sandi geser yang menjadi suvenir Museum Sandi. Sandi geser biasanya diberikan diawal memasuki museum, akan tetapi pada program ini dilakukan improvisasi menjadi sebuah kuis agar lebih menarik.

Pada scene ini juga ditambahkan intruksional tentang tata cara membaca sandi geser. Penjelasan tata cara membaca sandi geser ditampilkan dengan menggunakan grafis, agar lebih menarik dan dapat dipahami oleh penonton. Narasi untuk grafis ini juga dilakukan oleh petugas Muna untuk tetap menjaga kontinuitas dari penyampai informasi di episode ini.

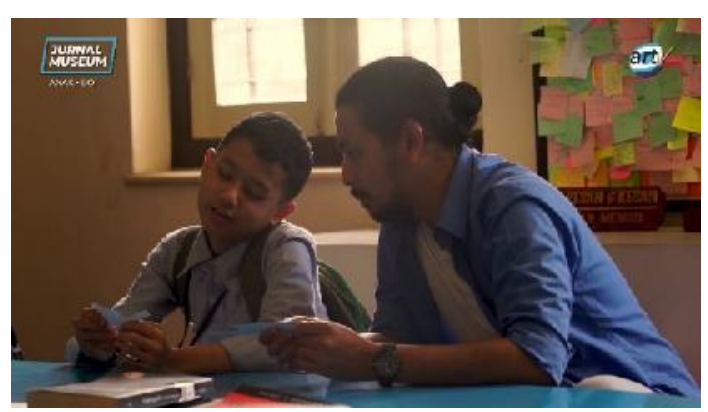

Gambar 18. Screenshot adegan Ayah dan Arbi memahami penjelasan petugas Muna

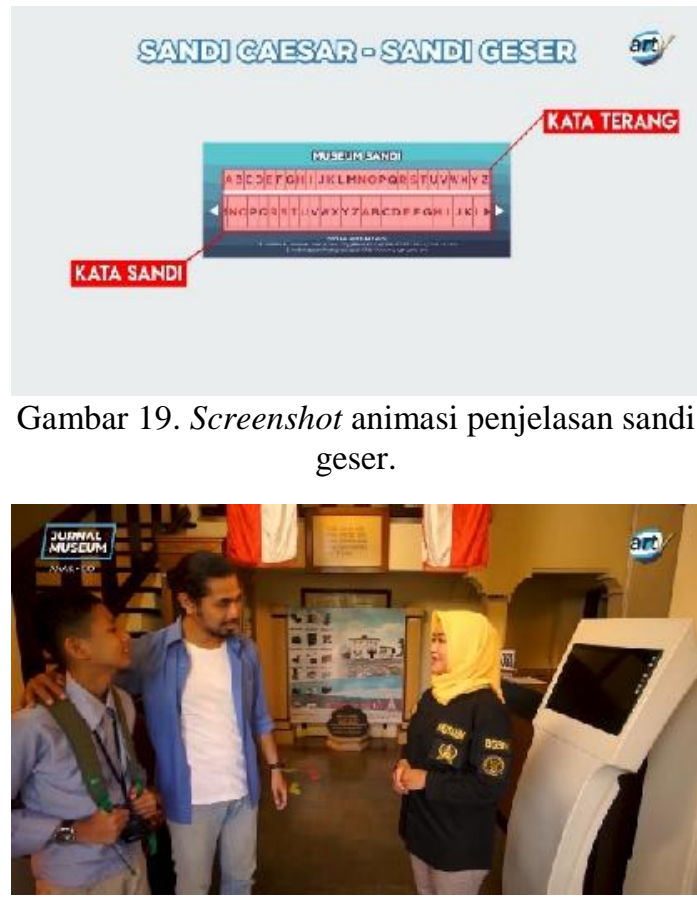

Gambar 20. Screenshot adegan Ayah dan Arbi berpamitan dengan petugas Muna

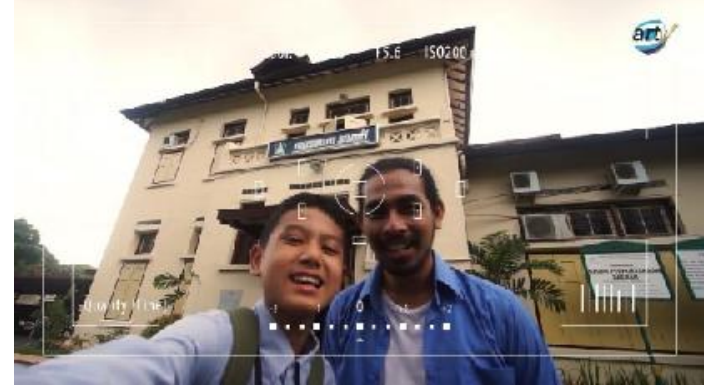

Gambar 21. Screenshot adegan Ayah dan berfoto di depan Museum Sandi

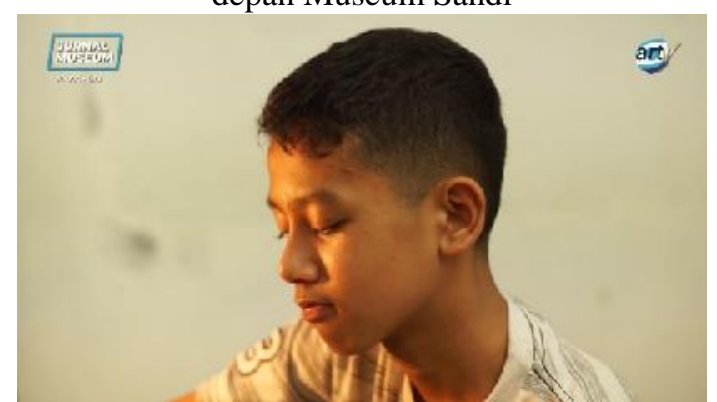

Gambar 22. Screenshot adegan Arbi menulis hasil perjalanannya 
Scene selanjutnya merupakan scene singkat yang memperlihatkan Arbi dan Ayah selesai mengunjungi Museum Sandi dan berpamitan dengan petugas Muna. Scene ini diadakan untuk menunjukkan tokoh Arbi dan Ayah berterima kasih kepada petugas Muna karena telah diberikan pelayanan selama berkeliling di Museum Sandi.

Scene ini juga merupakan scene singkat yang memperlihatkan Arbi dan Ayah berfoto di depan gedung museum sebagai bukti bahwa pernah berkunjung ke Museum Sandi. Scene ini akan berhubungan dengan scene setelahnya dimana hasil foto akan ditempel pada buku catatan milik Arbi sebagai bukti telah mengunjungi Museum Sandi. Adegan berfoto ini juga merupakan adegan wajib yang akan diadakan disetiap episodenya.

Scene penutup untuk episode kali ini. Memperlihatkan Arbi sedang menulis catatan harian tentang perjalanannya di Museum Sandi. Pada scene ini terdapat narasi (voice over) tentang kesimpulan episode kali ini yang ditulis Arbi dibuku catatannya mengenai sandi, dan Museum Sandi. Shot terakhir sebelum credit title ini diperlihatkan sampul buku catatan Arbi yang bertuliskan "Jurnal Museum” yang merupakan identitas program itu sendiri.

\section{Kesimpulan}

Merujuk pada fungsi edukasi (education) dan hiburan (entertainment) dalam media televisi atau yang sekarang sering disebut edutainment, merupakan salah satu poin penting dalam pembuatan program televisi feature "Jurnal Museum" yang mengangkat tentang tema sejarah dan museum. Program "Jurnal Museum” adalah sebuah program feature yang mengangkat topik bahasan tentang sejarah melalui musem-museum dengan pengemasan menggunakan pendekatan naratif atau pendekatan bercerita. Konsep yang diusung pada program feature ini yakni menyajikan sebuah cerita tentang Arbi (Anak) dan orangtuanya mengunjungi museum-museum untuk menjawab pertanyaan Arbi tentang hal-hal yang ada disekitarnya berhubungan dengan sejarah. Pendekatan naratif digunakan sebagai penggambaran sebab akibat dalam pemilihan topik bahasan dan museum yang dikunjungi.

Program feature "Jurnal Museum" ini ingin mengajak penonton khususnya anakanak dan orangtua untuk belajar mengenai sejarah dengan mengunjungi museummuseum yang ada di Indonesia sehingga museum dapat menjadi tempat wisata edukasi yang diminati lagi dan dapat mendapatkan apresiasi lebih. Pada episode kali ini menayangkan perjalanan Arbi dan Ayah mengunjungi Museum Sandi untuk menjawab pertanyaan Arbi mengenai persandian yang didapatkannya dari ekstrakulikuler pramuka di sekolah. Kunjungan Ayah dan Arbi hanya akan memperlihatkan ruangan-ruangan yang 
berhubungan dengan topik bahasan, dalam episode ini adalah tentang sejarah persandian di Indonesia. Pada program ini juga dibantu dengan media animasi serta grafis dalam penyampaian koleksi-koleksi yang berhubungan dengan sejarah persandian di Indonesia.

Pada karya program feature "Jurnal Museum" ini berdurasi 24 menit dengan pembagian tiga segment masing-masing segment berdurasi kurang lebih 8 menit. Program feature "Jurnal Museum" ini juga menekankan informasi gambar dan cara penyampaian informasi yang komunikatif melalui obrolan Arbi dan Ayah dengan tokoh petugas museum. Dalam proses penciptaan program feature ini berjalan dengan baik dari proses praproduksi hingga pascaproduksi walaupun terdapat beberapa kendala. Kendala-kendala yang terjadi baik di lapangan maupun di teknis dapat diatasi dengan cara mengkomunikasikan kembali kepada kerabat kerja dan pemain, serta meminta pertimbangan dari narasumber.

\section{Daftar Pustaka}

Egi Istiqomah, Masnur. 2017. Buku Panduan Pengunjung Museum Sandi. Yogyakarta.

Gumelar, M.S. 2002. Memproduksi Animasi TV: Solusi Murah \& Cepat. Jakarta: PT.Gramedia.

Morrisan, M.A. 2008. Manajemen Media Penyiaran: Strategi Mengelola Radio \& Televisi Edisi Revisi. Jakarta: Kencana Pranadamedia Group

Naratama. 2013. Menjadi Sutradara Televisi: dengan Single dan Multi Camera.Jakarta: Grasindo

Parsuki, Drs, 1987.Buku Diklat Dasar Dasar Animasi, Program Studi DKV jurusan Desain FSRD ISI Yogyakarta

Pratista, Himawan. 2008. Memahami Film. Yogyakarta: Homerian Pustaka

Rabiger, Michael. 2000. Developing Story Ideas. United States of America: Focal Press.

Ron Ayawaila, Gerzon. 2008.Dokumenter Dari Ide Sampai Produksi.Jakarta: FFTV-IKJ Press.

Sastro Subroto, Darwanto. 2007. Televisi Sebagai Media Pendidikan. Yogyakarta: Pustaka Pelajar

Sutisno, P.C.S. 1993.Pedoman Praktis Penulisan Skenario Televisi dan Video, Jakarta: PT.Gramedia Widiasarana.

Wibowo, Fred. 1997. Dasar-Dasar Program Televisi, Jakarta: Grasindo.

Zoebazary, Ilham. 2010. Kamus Istilah Televisi \& Film. Jakarta: PT.Gramedia 